\title{
THE MANAGEMENT POLICY OF STATE LANDS AS AFORMER OFRIGHT TO CULTIVATEIN REJANG LEBONG REGENCY
}

\author{
By:
}

Azman Hadi, Herawan Sauni, Hamdani Ma'akir

\begin{abstract}
This research raises the issues related to the management of state lands as a former of right to cultivatein Rejang Lebong Regency.In 1988, PT.Bumi Megah Sentosa obtained the right to cultivatefor an area of 6,925 hectares. The process of obtaining right to cultivate is gotten through community land acquisition, but PT. Megah Bumi Sentosa was not able to free it entirely therefore the right to cultivate was canceled.This research aims to find out and explain the management of state lands as a former of right to cultivatein Rejang Lebong Regency and the obstacles faced in the management of state lands as a former of right to cultivate in Rejang Lebong Regency.This research is sociological juridical with a qualitative approach.The analysis used in data management is qualitative analysis, namely the data obtained is selected based on the quality and truth according to its relevance to the research material. This research was conducted in the Rejang Lebong Regency of Bengkulu Province.The results of this research indicate that the management of state lands as a former of right to cultivate in Rejang Lebong Regency has not been maximized by the local government. On the former land ofright to cultivate, there are transmigration settlements that have no management rights and control of the original landowner community. The obstacles in the management of state lands as a former of right to cultivatein Rejang Lebong Regency were the different perceptions between the Regent of Rejang Lebong Regency with the Office of the Ministry of Agrarian and Spatial Planning / National Land Office of RejangLebong Regency.This research offers a scheme of alternative solutions to its main policies: Strengthening Community Rights with Agrarian Reform.
\end{abstract}

Keywords: State Land Management, Right to Cultivate 


\section{A. INTRODUCTION}

\section{Background of Research}

Indonesia is one country that has a large land area.With a land area reaching 191.09 million hectares, it is the largest 10 (ten) largest country in the world. The extent of this land area is a blessing and a gift from the Almighty, as well as a big job for the government and society at Indonesia to manage it. Along with population growth and the shift to industrialized countries has led to increasingly strategic and increasingly complex agrarian management, spatial planning and land in Indonesia.The total area of Indonesia is approximately 840 million hectares, consisting of 191 million hectares of land and 649 million hectares of ocean. From the land area, about 124.19 million hectares $(64.93 \%)$ are still in the form of forests. The remaining 67.08 ha $(35,07 \%)$ has been

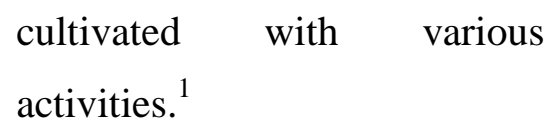

Article 33 paragraph (3) of the 1945 Constitution mandates the state to be able to prosper the people through natural resource management in Indonesia.The StateOwnership Rights $(H M N)$ has the authority to regulate the control, use and utilization of natural resources through the granting of authority, supervision and regulation in each of the other ministries / government institutions.

Indeed, the UUPA was made to regulate land ownership and management and agrarian resources. The UUPA states that all Indonesian people, especially the peasants and indigenous peoples, have the right to control and manage land for the people's welfare. Almost

\footnotetext{
${ }^{1}$ Attachment 1 Minister of Agrarian and Spatial Planning / Head of the National Land Office Number 25 of 2015 concerning the Strategic Plan of the Ministry of Agrarian and Spatial Planning / National Land Office for 2015-2019 p.4
} 
half a century, after the birth of the UUPA, land ownership did not side with the small people. The ratio of land tenure in Indonesia is close to 0.58 . Its mean that only about $1 \%$ of the population controls $59 \%$ of agrarian, land and space resources. $^{2}$

President JokoWidodo revealed that most farmers in the village are landless farm workers and smallholders who only have less than 0.3 hectares of land per person. ${ }^{3}$ The issue of inequality in land tenure and access to land for farmers in rural areas is due to government policies since the New Orde era, the government through policy opened up the opportunities as much as possible to the owners of

2 "Ini dia capaian program strategis ATR/BPN", Yokatta Magazine 27 Edition of III, 22 ${ }^{\text {nd }}$ Oktober-22 $2^{\text {nd }}$ November, 2017.

${ }^{3}$ Bey Machmudin, "PresidenJokowi : Lakukan segera Reforma Agraria", http://www.bpn.go.id/Berita/Siaran-

Pers, Accessed on Agustus 25 ${ }^{\text {th }}, 2016$ at21.00WIB. capital to control and own people's land for economic growth, therefore land became a commodity .

The agricultural policy in the new orderoriented towards economic growth has resulted in the occurrence of change in perceptions on land function as one of the unique natural resources. This is supported by changes in land policy (propeople become prokapital) which proved to be getting away from embodiment equitable development results, and it means that the more difficult to achieve social justice. ${ }^{4}$

The same thing was also expressed by Herawan Sauni that legal policy in that era was directed at efforts to facilitate development activities that were the priority of the period. At that time the

${ }^{4}$ Maria S.W.Sumardjono, "Tanah dalam perspektif hak ekonomi sosial dan budaya", PT.Kompas Media Nusantara, 2008, Jakarta. P.70 
Indonesian nation was actively implementing development in all fields, especially growthoriented economic development, in the development of development law directed towards achieving economic development. In this era the law was called " a tool of social enginnering " for economic growth. ${ }^{5}$

The MPR Decree No.IX / MPR / 2001 on Agrarian Reform and Natural Resources management has provided a glimmer of hope for those who depend on agricultural sector, especially farmers and farm workers who have not been able to enjoy the fruits of development more equitably and honored.

However, along with the pace of development which at this time has entered the era of reform problems and challenges in the field of land

\footnotetext{
${ }^{5}$ HerawanSauni, "Implikasi
} Hukum Terhadap Pelaksanaan Program Landreform di Indonesia", Equality Journal Vol.11 Nomber 1, 2006, P. 3233. seem to continue to roll. Mastery and land use conflicts between actors and community groups involved in development continue to color the nation's journey. ${ }^{6}$

In Rejang Lebong Regency there are 3 (three) holders of Right to cultivate, namely: PT.Sembada Nabracom location in Sentral Baru Village Bermani Ulu District covering an area of 292 hectares of cocoa plantations based on Decree Number 36/HGU/BPN/1989 dated in June $27^{\text {th }}$, 1989 with certificate of $H G U$ Number 1 which will expire on December $31^{\text {th }}$, 2018. Next is PT.Budi Putra Makmur, located in Kayu Manis Village, Selupu Rejang Subdistrict covering 301 hectares of Arabica coffee plantations based on Decree Number 22/HGU/BPN/1989 dated in April 6 ${ }^{\text {th }}, 1989$ with

\footnotetext{
${ }^{6}$ HerawanSauni, "Politik Hukum Agraria Kajian Atas Landreform Dalam Rangka Pembangunan Hukum Ekonomi Indonesia, Pustaka Bangsa Press, 2006, Bengkulu. P. 5
} 
certificate of $H G U$ Number 1/S/CRP/1989 which will expire on December $31^{\text {th }}, 2019$.

The third holder of right to cultivate and became the object of this research is PT.Bumi Megah Sentosa (BMS) which is located in Kota Padang district with the area of 6925 hectares by the decree of Minister of Home Affairs No. 03/HGU/1988 dated on February $12^{\text {th }}, 1988$ with a periode of 30 years for cocoa plantations and will expire on December $31^{\text {st }}, 2017$. The granting of right to cultivate to PT.Bumi Megah Sentosa has caused people to lose access to agricultural land and lose livelihood resourcesto meet their daily needs. This is because the land that given to the right to cultivate even though it came from reserved land for large plantations, infactthe land was not a Free State land but the land of the farmers who belong to the community of Suku Tengah

Kepungut. ${ }^{7}$

These abandoned plantations are then cultivated by the community with coffee and rubber gardening. Based on data collected by the Akar Bengkulu, in 2013 there were about 414 Patriarch or approximately 1,678 people, who live on the plantation cultivation. ${ }^{8}$ In fact, this amount has increased again

${ }^{7}$ Suku Tengah Kepungut is one of the indigenous communities in the Administrative Region of RejangLebong Regency, Bengkulu Province, administratively entered into the District of Kota Padang. Historically it was a unit of the Lembak Nation and was located along the HuluMusi watershed with a pattern of customary institutions with the Marga system which was based on geneological and territorial grounds and was headed by Pasirah. This customary institutional system refers to a family pattern that arises from a unilateral and patrilineal lineage and an exogamous marriage. But then the Local Indigenous Institution system called Marga was removed through Law No. 5 of 1979 concerning Village Government.

${ }^{8}$ Sugian Bahanan, "PengembalianHakUlayatSuku Tengah Kepungut", http://www.akar.or.id/index.php/2013/0 1/18/pengembalian-hak-ulayat-sukutengah-kepungut/ on February $20^{\text {th }}, 2016$ at22.15 WIB. 
according to Sukaesih as many as 489 Patriarch who worked on the former land of right to cultivate. $^{9}$

The relatedto the amount of abandonment of right to cultivate by the rights holder, the analysis of Anton Lucas and C. Warren was quoted by Salim interesting to see. The emergence of largescale policy in the New Order Era issued by National Land Office by issuing location permits and granting right to cultivate eventually lands that are not used or abandoned. In fact, many of their attendants then mortagage it to the bank, but after getting enough money they did not cultivate or abandon their land. ${ }^{10}$

${ }^{9}$ Sukaesih, "Penguasaan Tanah Negara Bekas Hak Guna Usaha PT.Bumi Mega Sentosa oleh masyarakat di Kecamatan Kota Padang Kabupaten Rejang Lebong", Thesis of Universitas Bengkulu, of 2017 P. 61

${ }^{10} \mathrm{M}$ Nazir Salim, "Membaca Karakteristik Dan Peta Gerakan Agraria Indonesia", Bhumi Journal, STPN Yogyakarta, Number 39 of 13, April 2014, P. 418.
The management of state land is one of the elaborations of the government task in the land sector, while the task of government in the land sector itself is one of the elaborations of the authority to Control State's Right ${ }^{11}$. After being canceled and revoked the Decree of Granting Rights to the PT.Bumi Megah Sentosa by the National Land Office in 2000 , it turns out that until 2017 the former land for right to cultivate has not yet followed up the control and the Right to Cultivateby the Regional Government of RejangLebong Regency. This condition lasted a dozen years without any maximum effort from the Regional Government of RejangLebong Regency.Based on thedescription above, then

${ }^{11}$ State Ownership Rights are affirmed in the state constitution, namely Article 33 paragraph (3) of the 1945 Constitution which states: "Earth and water and natural resources contained therein are controlled by the state and are used for the greatest prosperity of the people." 
author interested in conducting this research with the title 'The Management Policy of State Lands as aFormer of Right to Cultivatein Rejang Lebong Regency".

\section{Identification of Problems}

Based on the
description above, the
identification of the problems
to be studied in this research
are as follows, namely:

1. What is the management policy of state lands as aformer ofright to cultivate in RejangLebong Regency?

2. What are the obstacles and solutions in the management of state lands as a former ofright to cultivate in RejangLebong Regency?

\section{B. RESEARCH METHODS}

This research was asociological juridical orempirical, namely reviewing the applicable legal provisions and what happens in reality in society.Or in other words, a research conducted on the actual situation or real situation that occurs in the community with the intention to find out and find the facts and data needed, after the data needed was collected then leads to the identification of problems which ultimately lead to the resolution of the problem.

The method approach used in the research for writing this thesis was used a qualitative approach.A qualitative approach is an approach that emphasizes in terms of direct observation in a participatory manner from the researcher so that the phenomena that occur as well as the background can be revealed. In this approach, the sharpness and precision of the researcher was needed in observing and drawing conclusions on visible phenomena.

The primary data in this study were obtained by collectingdata through interview techniques with informants who are directly involved and then the data was processed by the author himself. The informants who are the primary data sources in this research were: 
a. Regent of RejangLebong Regency

b. Head of Regional Office of the Ministry of Agrarian and Spatial Planning / BPN of Bengkulu Province

c. Head Office of the Ministry of Agrarian and Spatial / BPN of RejangLebong Regency.

d. Sub-Division Head of Land Reform and Land Consolidation of Ministry of Agrarian and Spatial Planning Office / National Land Office of Rejang Lebong Regency.

e. Department Head of the Department of Social Affairs, Manpower and Transmigration, Rejang Lebong Regency.

The secondary data in this research included books and research in the forms of report, S1 research report, thesis, and journal. Besides that, this research also needed the secondary data that were collected from various government institutions, among them were: Central Statistic Body of Rejang Lebong Regency, Welfare Offices, Human
Resources and Migration of Rejang Lebong Regency.

The data analysis method that was used in this research was qualitative analysis, where the data obtained for this research, either primary or secondary were selected based on the quality and validity relevant to the research material. The data analysis was conducted by with drawing a connection between the field data and theoretical elements or law decision. This research data were analyzed qualitatively by describing the state land management policy on the land which was previously used as Right to Cultivate in Rejang Lebong Regency and investigating any alternative solution that could be taken. Then, the researcher analyzed the obstacles of state management which was previously used by Rights to Cultivate in Rejang Lebong Regency, so the root problem could be located as well as the possibly applicable solution to make the state land management be better. 


\section{RESEARCH RESULT AND DISCUSSION}

1. The Land Claim of PT. BumiMegahSentosa' Right to Cultivate.

The land claim of Right to Cultivate of PT. Bumi Megah Sentosa can be traced back to the letter number: HK.350/Ec.220, Minister of Agriculture Cq. Farming General Director that gives an agreement for the principle of the development of cocoa plants with 7,000 hectare in the area of Padang Ulak Tanding District of Rejang Lebong Regency, Bengkulu Province. Giving the agreement of the principle of Cacao plants development to the PT. Bumi Megah Sentosa is based on the letter of request for license of the development of Cacao plants in Bengkulu from the director of PT. Bumi Megah Sentosa Land Number S.1186 in $6^{\text {th }}$ of November 1986.

Then, based on the the review result of the land consideration team for the development of production development business in Bengkulu Province in $11^{\text {th }}$ of November 1988, the Bengkulu province Governor gave a principle agreement for the reserving land which was 7000 hectare for cacao plantation registered as PT. Bumi Megah Sentosa with a letter Number 525/3083/B.6/86 on November $17^{\text {th }} 1986$.

In responding to that principle agreement, on the $6^{\text {th }}$ of Pebruary 1987, Regional Capital Investment Coordinating Board of Bengkulu Province sent letter sent to Regent / The Level II Regional Chairman of RejangLebong Regency to give full support to the PT. Bumi Megah Sentosa in order to run Cacao Plantation Event in RejangLebong Regency Area. 1213 After that, PT. Bumi Megah Sentosa through the

12 See the copy of Regional Capital Investment Coordinating Board letter of Bengkulu Province Number $1425 /$ II/BKPMD/1987 on $6^{\text {th }}$ of February 1987. 
letter number 13 dated on $6^{\text {th }}$ of

February 1987 proposed location license request and land acquisition/ purchase with 7000 hectares located in Derati Village Subdistrict of Padang Ulak Tanding of Rejang Lebong Regency. That proposal was granted by the Governor of Bengkulu Province through a Letter of Decision Number: 160/IL/II/BKPMD/1987 on March $14^{\text {th }} 1987$ in Location Permit and Land Acquisition/ Purchase on 7000 hectares for the Cacao Plantation registered as PT. Bumi Megah Sentosa on Derati Village of Padang Ulak Tanding Subdistrict of Rejang Lebong Regency.

PT. Bumi Megah Sentosa applied for Right to cultivate using a recommendation from Capital Investment Coordinating Board of Jakarta on $21^{\text {st }}$ of July 1987 Number 433/A.4/1987.

Because of that request, The Land Investigation Committee B of Bengkulu Province in its summary on the $27^{\text {th }}$ of June 1987 Number 11/RSL/B/1987, stated that that request could be granted to be given the Right to Cultivate for the area of 7000 ha because that location had been set for a big Plantation in Bengkulu Province. That requested land of the Right to Cultivate by PT. Bumi Megah Sentosa, after being treated using Cadastral measurement; it was found that the circumference of 6925 hectares put on the Situation Map dated on $31^{\text {st }}$ of August 1987 Number 20/1987.

Beside that, The Council Team of Right to Cultivate of the Big Plantation in Jakarta has given their consideration to the Minister of Internal Affair to make that request be granted, being given the right to cultivate for 30 year on the land as wide as 6925 hectares. Based on that, the letter of decision of minister of Internal Affair Number $03 / \mathrm{HGU} / 1988$ on $12^{\text {th }}$ of February 1988 on the grant for 
the right to cultivate registered as PT. Bumi Megah Sentosa, with specific purpose of Cacao.

The letter of decision of Minister of Internal Affairs Number $03 / \mathrm{HGU} / 1988$ on $12^{\text {th }}$ of February 1988 is the basis of the issuance of Right to Cultivate for Business Certificate Number 1/RL/1988 registered as PT. Bumi Megah Sentosa, located in Jakarta particularly Merantau Village, Lubuk Belimbing I, Karang Baru, Tanjung Heran, Suka Merindu, Kikim, Lubuk Mumpo, Kota Padang, Suka Rami, and Taba Anyar Subdistrict of Kota Padang, Rejang Lebong Regency with situation picture Number 134/1988 on $14^{\text {th }}$ of April 1988 with 6925 Hectares.

\section{Revocation of Right to $\begin{array}{lll}\text { Cultivate of } & \text { PT. }\end{array}$ \\ BumiMegahSentosa \\ On the $24^{\text {th }}$ of} November 1999 there was a letter Number 525.29/889/6 stated that based on the classification of Plantation
1997/1998; the plantation lands that were located in Rejang Lebong Regency including Plantation of Class V were untreated. Then, the Governor, the Provincial Head of Bengkulu Province with the letter Number 167/1999/I/B.1 proposed a revocation right on the Plantation Lands of PT. BumiMegahSentosa. Then, the General Director of Plantation, Forestry Department and Plantation on the date of February $18^{\text {th }} 2000$ with the letter Number 88/VIIPKU/2000 also proposed a revocation on the Grant of Right to Cultivate and Revocation on the Plantation Land of PT. BumiMegahSentosa to the Head of National Lands Authority (BPN). In addition, the Regional Head Office of National Land Authority (BPN) of Bengkulu Province with the letter number $500-081$ on $31^{\text {st }}$ of January 2000 proposed to the Head of NLA of RI to revoke 7 (seven) of right to 
cultivate for the untreated lands in Bengkulu Province, one of them was the right to cultivate of PT. BumiMegahSentosa.

In the year of 2000 , the letter of decision of The Head of National Land Authority (BPN) No.11-VIII2000 on the revocation of the Right to Cultivate and Letter of Decision of Rights to Cultivate on Lands located in Bengkulu Province.

\section{The Management of State} Lands as a Former of Right to Cultivate of PT. BumiMegahSentosa

$$
\begin{aligned}
& \text { Since the Right to } \\
& \text { Cultivate was revoked and } \\
& \text { rescinded, that lands were } \\
& \text { cultivated by the surrounding } \\
& \text { society as plantation several } \\
& \text { people have ever proposed a } \\
& \text { request of right of possession to } \\
& \text { the office of land of Authority } \\
& \text { of RejangLebong Regency. } \\
& \text { However, that request was } \\
& \text { always rejected as the office of } \\
& \text { Land Authority always held to } \\
& \text { the Letter of Bengkulu }
\end{aligned}
$$
Governor Number 286/2002 on $6^{\text {th }}$ of June 2002 on the Regulation of the right to cultivate and for possession of land for the former lands of Right to Cultivate located in the Regency of RejangLebong.

\section{a. the Proposal for the Land} Location of Land Reform Object.

Even as collectively has even been proposed by the village of Sukamerindu and Sukarami. In responding to that request, the office of Land of Authority in 2016 made an effort to make the Land Reform Object (TOL) which was planned to be distributed to the society. The first step taken by the Office of Land Authority of RejangLebong Regency was conducting initial survey. The purpose of this survey was to ensure that the land condition should be free from any disputes or clear or clean. $^{14}$

${ }^{14}$ The interview result with Subsection Head of The Land Authority Office of RejangLebong Regency, on $6^{\text {th }}$ 
Based in that initial survey result, the head of land authority office of RejangLebong Regency by letter Number 148/1$17.01 / \mathrm{III} / 2016$ propose the location of event for the land certification through land redistribution occasion. Based on that proposal, the regional office of Land Authority Issued a Letter of Decision Number 25/Kep$17.14 / \mathrm{I} / 2016$ on the $28^{\text {th }}$ of January 2016 on the location decision of the Land Reform Object Redistribution in Bengkulu Province budget year of 2016, one of the contents declares the areas of Kota Padang District consisting of 5 villages which were: Subdistrict of Kota Padang, TabaAnyar Village, Sukarami, LubukMumpo and Derati.

Accroding to the Letter Number 19/117.01/1/2016, the Head of Land Auhority Office of

of March 2018, at 08:30 IWST.
RejangLebong Regency asked the Subdistrict Head of Kota Padang, The Village Chief of TabaAnyar, the Village Chief of Derati, The Village Chief of LubukMumpo and The Village Chief of Sukarami to enlist the society who cultivated the former lands of right to cultivate of PT. BumiMegahSentosa, which can be seen at the table 1 as follows:

Table 1: The Number of Farmer that Cultivated Former Land of Right to Cultivate of PT. BumiMegahSentosa in

RejangLebong Regency.

\begin{tabular}{|l|l|c|c|c|}
\hline $\mathbf{N}$ & $\begin{array}{l}\text { Subdistri } \\
\text { ct/ }\end{array}$ & $\begin{array}{c}\text { Num } \\
\text { ber } \\
\text { Village }\end{array}$ & $\begin{array}{c}\text { Land } \\
\text { of } \\
\text { Farm } \\
\text { ber } \\
\text { er }\end{array}$ & $\begin{array}{c}\text { The } \\
\text { Width } \\
\text { of } \\
\text { Cultiv } \\
\text { ated } \\
\text { Land } \\
\text { (Ha) }\end{array}$ \\
\hline 1 & $\begin{array}{l}\text { Kota } \\
\text { Padang }\end{array}$ & 122 & 197 & 333 \\
\hline 2 & TabaAny & 73 & 98 & 210 \\
ar & & & \\
\hline
\end{tabular}




\begin{tabular}{|l|l|c|c|c|}
3 & Derati & 118 & 245 & 257 \\
4 & $\begin{array}{l}\text { LubukMu } \\
\text { mpo }\end{array}$ & 50 & 115 & 150 \\
5 & $\begin{array}{l}\text { Sukarami } \\
\text { Source: }\end{array}$ & 32 & 64 & 90 \\
\hline & Office of & Agrarian and \\
Spatial Planning/National \\
Land of Authority of \\
RejangLebong Regency, \\
2018
\end{tabular}

\section{b. Application of Rights to}

\section{Manage Migration}

Based on the interview result with the former of Head of Land Authority Office of RejangLebong Regency, Mr. Supriyadi, BR, (now he serves as Head Division of the Procurement of Land for National Land Authority of Bengkulu Province, as the follow up of the letter of decision. The Head of BPN Number 11-VIII-2000, Governor issued Letter of Decision Number 65 year of 2000 on $01-04-2000$ on the Cultivating team formation of former Right to Cultivate Land in Bengkulu Province. Furthermore, Governor also issued Letter of Decision Number 2862002 on the Regulation of Possession and Cultivation of Land towards the former land of the Right to Cultivate one that was located in the RejangLebong Regency. ${ }^{1514}$ However, before the issuance of the Governor Letter of Decision Number 286 2002, the Regent of RejangLebong Regency had also issued the Decree of Regent number 6312001 on the Appointing of Land Reservation for Origin Settlement Location of General Migration and Surrounding Settlers, Handling of Forest Encroachment and Refugees Resettlement in

${ }^{15}$ See the Governor's Letter of Decision Number 2862002 Point three states that the regulation of claim and cultivation of land mentioned int the first and second ones of this decision the implementation was referred to the Regent of RejangLebong. 
RejangLebong Regency at the second dictum stated that:

The area of land with 9,400 $\mathrm{Ha}$ as stipulated in the first dictum of this decision is located in:

1. District of LebongAtas : $1200 \mathrm{Ha}$.

2. District of North Lebong

$$
\text { : } 1000 \mathrm{Ha}
$$

3. District of Padang UlakTanding

$$
\text { : } 1800 \mathrm{Ha}
$$

4. District of Kota Padang

$$
\text { : } 5400 \mathrm{Ha}
$$

The follow-up action of the Decision of Regent of Rejang Lebong, people in Lubuk Mumpo Village on the $5^{\text {th }}$ of Mei 2004 agreed through the Decision of Lubuk Mumpo Village Number $110 / 08 / L P / 2004$ on the Proposal/Request for General Migration
Settlement/ Forest Encroachment/Resettlement of Refugees to propose to the Government of RejangLebong to bring migrants to Lubuk Mumpo Village. The People of Lubuk Mumpo Village propose infrastructure building through sector of Migration settlement with 150 Head of Family from Place of Origin (Java Island) and 150 Head of Family Surrounding People. In 2006, the $150 \mathrm{Head}$ of Family of migrants from Java Island ware being brought to the location of Lubuk Mumpo Village, but the blur of location border of Migration reservation on the field had caused this program run as expected. On the field, a conflict between the migrants and the local people occurred, therefore many migrants left their land locations. ${ }^{16}$

\footnotetext{
${ }^{16}$ Interview Result with
} Muhammad Ali, S.H. Head Division of 
Finally, in 2017, Head of the Office of Manpower and Migration of Rejang Lebong Regency Dwi Purnama Sari, S.Sos., M.M. on behalf of the Ministry of Village, Development of Under Developed Region and Migration of Republic of Indonesia Applied for a request to Right of Management to the Office of Agrarian and Spatial Order/ National Land Authority of Bengkulu Province with 1775 Ha. Based on the measurement conducted by Regional Office of Agrarian and Spatial Order/National Land Authority of Bengkulu Province found that the available land was 987.3 ha.

Picture1. Map of HPL Land

Area OnLubuk Mumpo

Transmigration

Social Service Human Resources and Migration of RejangLebong Regency.

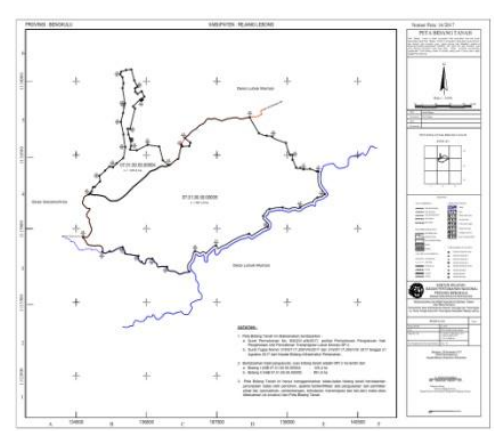

3. Affirmation Becomes Land of Object of Agrarian Reform (TORA)

Based on the Book on Realization of Asset Legalization Activities and Land Redistribution for 20152017 from the National Land Office, until 2017, the government has submitted $2,889,993$ land certificates. In 2018, the government increased the target for certificates to be distributed to the community to 7 million. In 2019, the target is increased to 9 million certificates. $^{17}$

In 2018, Bengkulu Province will have 10,000 parcels or plots of land in the agrarian reform launched by

${ }^{17}$ Eko Sulistyo, Nawacita Reforma Agraria, www.ksp.go.id/nawacita-reformaagraria/index.html,accessed on May $2^{\text {nd }}$ 2018 at 21.00 p.m. 
the central government, including 3,500 parcels will be distributed to RejangLebong Regency. ${ }^{18}$ Agrarian reform in the Province of Bengkulu since 2015-2018 originating from former Land for Right to Cultivate that is not renewed or renewed can be seen in the following table:

\section{Obstacles in the Management} of State Lands as a Former of Right to Cultivate of PT.

\section{BumiMegahSentosa}

The management of state land is one of the tasks of the government in the field of land which is the elaboration of the authority of the State's Right to Control. Article 2 of Presidential Regulation No. 10 of 2006 concerning the National Land Office states that the task of the National Land Office is the government's duty in the land sector nationally and regionally, then based on Article 2 of Presidential

\footnotetext{
${ }^{18}$ Nur Muhamad, Rejang Lebong dapat 3.500 sertifikat reforma agraria, https://bengkulu.Antaranews.com/berita/482 51/accessed on May $6^{\text {th }} 2018$ at 21.05 p.m.
}

Regulation No. 10/2006 it appears that the management of state land is the responsibility of the National Land Office. ${ }^{19}$

In fact, based on the Governor's Decree Number 286/2002 dated June 6, 2002 concerning Regulations on the Control and Use of the Former Land for Right to Cultivate located in the RejangLebong Regency of Bengkulu Province, the third dictum states that:

The regulation of control and Right to Cultivatereferred to in the first dictum and the second of these decisions was submitted to the Regent of RejangLebong.

According to the regent of RejangLebong Regency through the Head of Government Section, the former lands of Right to

\footnotetext{
${ }^{19}$ OloanSitorus, et al. (2006). Pengelolaan Tanah Negara Bekas Hak Guna Usaha Perkebunan Besar yang berakhir jangka waktunya di provinsi Sumatera Utara.Research Report of National Land Academy. Yogyakarta, P. 16.
} 
Cultivate is an asset of the Regional Government so that the regent has the right to determine policies in the management of the former State Land Use Rights, both for the interests of the regional government and for sharecroppers. $^{20}$

On the other hand, the RejangLebong Regency Land Office considers that the former state land of HGU PT. BumiMegahSentosa cannot immediately become an asset of the local government of RejangLebong district. There are several conditions for land to be an asset of the local government, namely (1) there must be a release of rights; (2) the purchase of land must use costs originating from the APBD; (3) the land must be registered as an asset and (4) the land must be certified. ${ }^{21}$ Differences in

${ }^{20}$ The interview results with Mrs. Dra. Nani Elvira, MM., The administration head of Government of Rejang Lebong Regency, on March $6^{\text {th }} 2018$, at 10.00 a.m.

21 The interview results with $\mathrm{Mr}$. Supriyadi, BR. Former Head Office of the perception between the District Head of Rejang Lebong Regency and the Office of the Ministry of Agrarian and Spatial Planning / National Land Office of Rejang Lebong Regency regarding the understanding and authority of the management as a former state land of right to cultivate PT. Bumi Megah Sentosa.This magnificent sentimental earth is a barrier in the efforts of the Rejang Lebong Regency Office of the Ministry of Agrarian and Spatial Planning / National Land Office to provide rights for sharecroppers.

Conditions in the field also occurred when the community acquired acquisitions because they felt that they had never received compensation from the PT. Bumi Megah Sentosa so that people claim that the land is still theirs. In terms of institutional implementation of

Ministry of Agriculture and Spatial Planning / National Land Office or RejangLebong Regency, on February $4^{\text {th }}, 2018$, at 09.30 a.m. 
Agrarian Reform, the tasks and functions of the Agrarian Reform Task Force at the provincial and regency levels are not yet optimal, this is due to the fact that it was only formed in 2018 and the Program has not yet synchronized. The asset legalization and land redistribution in the Ministry of Agrarian and Spatial Planning / BPN RejangLebong Regency.

\section{Solutions in the Management} as a Former State Landsof Right to Cultivate in RejangLebong Regency

There are several things that can be done by the Regional Government and the Ministry of Agrarian and Spatial Planning / National Land Office of Rejang Lebong Regency. Firstly, immediately determine the location of the former right to cultivate as the object of agrarian reform so that the process of strengthening the rights of cultivating communities can be carried out with agrarian reform, for which the local government must immediately inventory the number of farmers who work on the former lands of Right to Cultivate. Policies with an agrarian reform scheme can be implemented in order to provide legal protection for the people who control the country's land physically.

Secondly, the former lands of right to cultivate which will become the right to manage transmigration must be immediately followed up so that there is legal certainty for the transmigrants who occupy the land. Third, the regional government can propose part of the former lands of Right to Cultivateto become the assets of the local government by proposing to the Office of the Ministry of Agrarian Spatial Planning / National Land Office Rejang Lebong Regency as the Right to Use.

Fourth, in order for the program to run immediately, 
coordinate with relevant stakeholders, especially those who are members of the Agrarian Reform Task Force at the provincial and regency level, considering that achieving the target of Agrarian Reform requires good cooperation between stakeholders in the region. Fifth, Program Synchronization The provision of access to reform in the Regional Devices Organization (OPD) is related to asset legalization programs and land redistribution in the Ministry of Agrarian and Spatial Planning / National Land Office of Rejang Lebong Regency.

\section{CLOSING}

\section{Conclusion}

From the results of research and discussion on the management of state lands as a former of right to cultivate in RejangLebong Regency the following conclusions can be drawn:
1) The management of state lands as a former of right to cultivate in Rejang Lebong Regency has not been carried out maximally by the regional government or related agencies. The control of the former state land for business use rights of PT. Bumi Megah Sentosa by the community / cultivator farmers because PT. Bumi Megah Sentosa does not use its land in accordance with its intended use which results in the cancellation and revocation of the right to use the business. In addition, some people claim that the land at the location of the right to cultivateis still their land because the compensation process and their release were not completed by PT. Bumi Megah Sentosa.

2) Obstacles in the management of state lands as a former of right to cultivate in RejangLebong Regency are: 
a. There is a different perception between the Regent of Rejang Lebong Regency and the Office of the Ministry of Agrarian and Spatial Planning / National Land Office of the Rejang Lebong Regency regarding the understanding and authority of the management of state lands as a former of right to cultivate in PT. Bumi Megah Sentosa.

b. Acquisition by the community because they feel they have never received compensation from PT.

BumiMegahSentosatheref ore people claim that the land is still theirs.

c. In terms of institutional implementation of Agrarian Reform, the tasks and functions of the Agrarian Reform Task Force at the provincial and district levels are not yet optimal, this is due to the fact that it was only formed in 2018.

\section{Suggestions}

The suggestion that the author can give is that the management of state lands as a former of right to cultivate in the Rejang Lebong Regency is maximally as follows:

1. a. Immediately set the location of the former right to cultivate as the object of agrarian reform so that the process of strengthening the rights of the tenant community can be carried out with agrarian reform, policies with agrarian reform schemes can be implemented in order to provide legal protection for the people who control the country's land physically.

b. The former land of right to cultivate that will become the right to manage transmigration 
must be immediately followed up so that there is legal certainty for the transmigrants who occupy the land.

c. The regional government can propose part of the former land of right to cultivateto become the asset of the local government as the Right to Use.

2. a. Immediately do good coordination between stakeholders so that the implementation of asset structuring and arrangement of access can be carried out comprehensively and integrated, there must be readiness of village officials to carry out agrarian reform at the village level, and the readiness of village facilitators to encourage popular participation in the implementation of agrarian reform. b. Program Synchronization of the provision to reform access in the Regional Devices Organization $(O P D)$ is related to the asset legalization program and land redistribution in the Ministry of Agrarian and Spatial Planning / $B P N$ Rejang Lebong Regency.

\section{REFERENCES}

\section{Books :}

Herawan Sauni, 2006, Politik Hukum Agraria Kajian Atas Landreform Dalam Rangka Pembangunan Hukum Ekonomi Indonesia, Pustaka Bangsa Press, Bengkulu.

Maria S.W. Sumardjono, , 2001, Kebijakan Pertanahan Antara Regulasi dan Implementasi. Cetakan I. Penerbit Kompas, Jakarta.

Maria S.W.Sumardjono, 2008, Tanah dalam perspektif hak ekonomi sosial dan budaya, PT.Kompas Media Nusantara, Jakarta.

\section{Journal Research, Tesis, Skripsi :}

Herawan Sauni, 2006, Implikasi

Hukum Terhadap Pelaksanaan

Program Landreform di Indonesia, Jurnal Equality Vol.11 Nomor 1. 
Oloan Sitorus, dkk. (2006). Pengelolaan Tanah Negara Bekas Hak Guna Usaha Perkebunan Besar yang berakhir jangka waktunya di Provinsi Sumatera Utara. Laporan Peneliitian sekolah Tinggi Pertanahan Nasional. Yogyakarta.

Salim, M. Nazir. (2014). "Membaca Karakteristik dan Peta Gerakan Agraria Indonesia". Jurnal Bhumi, No. 39 Tahun 13, April 2014.

Sukaesih, (2017)."Penguasaan Tanah Negara Bekas Hak Guna Usaha PT.Bumi Mega Sentosa Oleh Masyarakat Kecamatan Kota Padang Kabupaten Rejang Lebong". Tesis. Jurusan Ilmu Hukum. Fakultas Hukum Universitas Bengkulu.

News Paper :

Majalah Yokatta Edisi 27 Tahun III. "Ini dia capaian program strategis ATR/BPN", , 22 Oktober-22 November 2017.

Strategi Nasional Pelaksanaan Reforma Agraria 2016-2019, Arahan dari Kantor Staf Presiden, Jakarta, 28 April 2016.

\section{Regulation :}

Republik Indonesia. Undang Undang Nomor 5 Tahun 1960 Tentang Peraturan Dasar Pokok-Pokok Agraria.
Republik Indonesia. Peraturan Pemerintah Nomor 8 Tahun 1953 tentang Penguasaan Tanah-Tanah Negara

Republik Indonesia. Peraturan Pemerintah Nomor 40 Tahun 1996 Tentang Hak Guna Usaha, Hak Guna Bangunan dan Hak Pakai.

Republik Indonesia. Peraturan Pemerintah Nomor 24 Tahun 1997 Tentang Pendaftaran Tanah.

Republik Indonesia. Peraturan Pemerintah Nomor 40 Tahun 1996 Tentang Hak Guna Usaha, Hak Guna Bangunan dan Hak Pakai Atas Tanah

Republik Indonesia. Peraturan Presiden Nomor 10 Tahun 2006 Tentang Badan Pertanahan Nasional.

Kementerian Agraria/Kepala BPN, Peraturan Menteri Negara Agrarial Kepala Badan Pertanahan Nasional Nomor 3 Tahun $1997 \quad$ Tentang Ketentuan Pelaksanaan PP Nomor 24 Tahun 1997.

Kementerian Agraria/Kepala BPN, Peraturan Menteri Negara Agrarial Kepala Badan Pertanahan Nasional Nomor 3 Tahun 1999 Tentang Pelimpahan Kewenangan Pemberian dan Pembatalan Keputusan Pemberian Hak Atas Tanah Negara. 


\section{Kementerian Agraria/Kepala BPN, Peraturan Menteri Negara Agrarial Kepala Badan Pertanahan Nasional Nomor 9 Tahun 1999 Tentang Tata Cara Pemberian dan Pembatalan Hak Atas Tanah Negara dan Pengelolaan.}

Badan Pertanahan Nasional, Peraturan Kepala Badan Pertanahan Nasional Republik Indonesia Nomor 2 Tahun 2013 Tentang Pelimpahan Kewenangan Pemberian Hak Atas Tanah dan Kegiatan Pendaftaran Tanah.

Badan Pertanahan Nasional. Peraturan Menteri Agraria dan Tata Ruang/Kepala Badan Pertanahan Nasional Nomor 25 Tahun 2015 Tentang Rencana Strategis Kementerian Agraria dan Tata Ruang/Badan Pertanahan Nasional Tahun 2015-2019.

\section{Website :}

Sugian, Bahanan. "Pengembalian Hak Ulayat Suku Tengah Kepungut”. Diakses melalui http://www.akar.or.id/index.ph p/2013/01/18/pengembalianhak-ulayat-suku-tengahkepungut/ pada tanggal 20 Februari 2016 pukul 22.15 WIB.

Bey Machmudin, " Presiden Jokowi - Lakukan segera Reforma Agraria", diakses dari http://www.bpn.go.id/Berita/Si aran-Pers, diakses tanggal 25 Agustus 2016.

Nur Muhamad, Rejang Lebong dapat 3.500 sertifikat reforma agraria, https://bengkulu.Antaranews.c om/berita/48251/diakses 6 Mei 2018 Pukul 21.05 WIB.

www.ksp.go.id/nawacita-reformaagraria/index.html, Eko Sulistyo, Nawacita Reforma Agraria, diakses tanggal 2 Mei 2018 Pukul.21.00 WIB. 